\title{
健康増進機能・環境親和性・先進安全性を併せ持つ 脚漕ぎ式搭乗型移動装置「ロハス・モビリティ」の展望
}

\author{
遠藤 央 $^{1 \dagger}$ \\ ${ }^{1}$ 日本大学工学部
}

\begin{abstract}
要旨：本研究では人力ロボティクスの概念に基づき, 人のペダリング運動を動力とするスマート・モビリティに関する技術開 発に取り組んでいる。このモビリティでは漕力の伝達量をクラッチにより操作することで, 車輪の回転軸まわりのトルクを制 御する。これにより自転車のようなペダル駆動の乗り物において，障害物や段差を回避する安全補助機能や，予設定された 道筋を走行する軌道追従機能などが実現できる。これだけでなく，入力である人間のペダリング運動を回生ブレーキと無段変 速機により制御する，自転車などは走行面の傾斜や凹凸，その走行状況により人間に対する負荷量が変化するが，提案するモ ビリティでは人間が継続してペダリング可能な状況を維持することが可能である. 最適な負荷量で長時間搭乗することで健康 増進がねらえる. 加えて疲労が蓄積しない負荷も実現できるため, 従来では原動機を搭載する乗り物で移動していた距離も, 提案モビリティにより移動することが期待できる．提案するモビリティはゼロエミッションであるため，環境親和性も良い． 本稿では，提案するシステムのコンセプトを紹介し，現在の開発状況について述べる.
\end{abstract}

キーワード：人力駆動ロボット，健康増進，持続可能性，安全制御，モビリティ

\section{1.はじめに}

人工知能や事象のモデル化技術などの急速な発展により， ある限定された環境において発生することが予想可能な事象 に対しては，その対処について学習または明確にルール化す ることで，システムが人間より最適かつ早急に判断を下せる 時代になった。一般環境でも, 利用シーンや対応する事象を 限定することで, 人間の判断よりシステムの判断が速さ・正 確さ共に優位的である場合が考えられる. ユーザが熟練者で はない場合には，特に該当する場合が多いと考える.

ここで自転車や車椅子などの乗り物や，ハンドリフトやウ インチなどの搬送機械に代表される, 非熟練者が多く利用す る人力を動力源とする機械を考える。このような人力機械に おいて知的動作を実現させる手法として, 菅原らにより人力 ロボティクスが提案されている ${ }^{1)}$. 人間機械協調系では, 人 間が判断しシステムが動力㧍よび駆動を司るものが提案され ている ${ }^{2,3)}$. 一方で人力ロボティクスでは, システムが判断 し人間が動力および駆動を司る. 具体的にはモー夕などの動 力源を用いず, 人力の出力への伝達量をシステムが操作する ことで, 運動を制御する。伝達量の制御にはパウダクラッチ1) や回生ブレーキ ${ }^{4)}$ を用いる手法が提案されている.

\section{7 年 1 月 17 日受付}

${ }^{\dagger}$ \% 963-8642 福島県郡山市田村町徳定字中河原 1

日本大学工学部機械工学科

遠藤 央

E-mail:m_endo@mech.ce.nihon-u.ac.jp
システムによる判断の重要なアプリケーションとして安全 性の向上が挙げられる。ロボットシステムの安全性について は古くから盛んに議論されており, ロボットシステムによる 作業の安全性向上のための技術の議論や, ロボットシステム そのものの安全性の議論など, 実用化・社会導入のために重 要な研究開発の要素である.

人力ロボティクスにおいては, 従来のロボットと同様に運 動制御により能動的に安全機能を実現できる. 加えて, 人 間の判断により動力供給を停止でき, いわゆるデッドマンス イッチのような受動的な安全機能も持ち合わせる.これらに より安全なシステムを実現可能であるとされる ${ }^{1)}$. 危険源を 特定することで, それに対しては人間よりも適切な運動を実 現できるうえ, 複雑な判断については搭乗者により対応でき るため, 脚漕ぎ式の乗り物 ${ }^{5)}$ や, 搬送装置 ${ }^{6}$, 医療デバイス への応用が期待されている.

\section{2. 人カ駆動型パーソナルモビリティ}

本研究では, 人力によりシステムが駆動される事に着目し, 環境および健康への親和性に配慮した搭乗型移動ロボット， いわゆるモビリティを研究している. システムが走行中に環 境を認識し, 知的判断をすることにより, 従来のパーソナル モビリティが有する危険回避や快適制御, 運転支援などの機 能が実現できる，また，前述したようにペダル運動を停止す ればモビリティ自体も停止するため, 受動安全を実現できる. しかも人力が動力源であるため環境負荷が極めて低いという 特徵もある. 加えて, 搭乗者の運動の機会を増やし健康増進 
を促すことも可能である.

人力を動力源とするモビリティの先行研究として, Takeda らによる歩行椅子 7) や高橋らによる人力移動ロボット ${ }^{8)}$ があ る.これらは人間の運動が機構を介して出力されることで, 移動のための運動を実現している．どちらも共に人力をその まま出力させる機構であり，出力をシステムにより制御でき ない，また，その機構構造の議論をしており，入出力のエネ ルギ効率の議論は不十分である.

出力を制御可能な人力駆動型モビリティとして, 鄭らによ る脚漕ぎ式倒立振子型モビリティが提案されている ${ }^{9)}$. この モビリティは，車輪軸にペダル軸とモー夕軸が共に固定され ており，車輪まわりのトルクはそれらの重㸚合わせが出力さ れる. 大まかな前進のための動力は人力によるが, モビリティ の倒立のための細かな車輪制御はモータトルクにより操作さ れる。したがって, 人力を打ち消すようモータトルクを発生 する場合があり，人力および電気的エネルギを有効に利用で きないことがある。

また，中川らによるパーソナルモビリティが提案されてい る. これは機械式 ${ }^{10)}$ と電気式 ${ }^{11)}$ の 2 通り提案されている. 機械式については鄭らの研究と同様の機構を持ち, 電気式は ペダル運動により発電したエネルギを用いて動作する. 前者 は先に指摘したエネルギ効率の課題を持つ。また, 後者は一 度発電をし, 蓄積したエネルギにより駆動するため, 各ステッ プにおいてのエネルギ効率が重畳され, エネルギ効率が低下 すると考えられる。

高橋らや平田らは足漕ぎ車椅子をべースとした医療福祉 のためのモビリティを提案している. 脚部ペダリング運動に より推進力を発生させ, 後部キャス夕へ機械的に固定された ジョイステイックにより操舵する。高橋らは段差乗り越えの ための出力側のパワーアシストを提案した ${ }^{12)}$. 平田らは乗 り味を改善するための入力側制御，具体的にはケイデンスと 呼ばれるペダルの角速度を一定にするために無段階変速機の ギア比を制御する手法を提案した ${ }^{13}$. これら研究は入出力側 の力・エネルギを補助することを実現しているが，操舵につ いては搭乗者が担うものである。

菅原らは人力ロボティクスを用いた倒立振子型モビリティ の実現を目的とし，独立対向二輪型移動ロボット KMM73を 提案している ${ }^{5)}$. 一定方向のペダリング運動を左右の車輪に 分配し, 各車輪をパウダクラッチによる人力ロボティクスの 機構を用いて制御することで, 前後進・回転の運動を実現す る. 人力が直接出力軸に伝達されるため, 高いエネルギ効率 が実現できる.また，人力駆動により知的動作を実現できる. しかしながら，人力の入力側には着目しておらず，入力が不 足する場合や急激に変動することが指摘されている.

\section{3. ロハス・モビリティ}

本研究で提案する環境および健康への親和性に配慮したモ ビリティをロハス・モビリティ（LOMO：LOHAS Mobility）
と呼称している。 ロハス (LOHAS : Lifestyles Of Health And Sustainability）とはRayらにより提案された概念であり，健 康で持続可能な生活様式を指す造語である ${ }^{14)}$. 人力ロボティ クスを用いるシステムであるため, ユーザの健康増進をねら え, かつ環境親和性の良いシステムであることより， ロ八ス のためのモビリティとして呼称している.

図 1 にロハス・モビリティのコンセプトを示す，健康で持 続可能な乗り物を実現するために，ロハス・モビリティには 安全および快適な運転を実現するための運動制御技術，人 間の長時間継続的なペダリングを可能にするための入力側 制御技術，および，エネルギ効率を向上するための動力伝 達技術が必要となる。 そのためにロ八ス・モビリティでは人 カトランスミッション (MPT : Man-Powered Transmission), 人力エネルギ回生システム (MERS : Man-powered Energy Regenerating System), エネルギ効率補償システム（EECS : Energy Efficiency Consumption System）から構成される.

\section{1 人カトランスミッション MPT}

ロハス・モビリティは，搭乗者の持続可能性のために安全 な走行が必要とされ，かつ健康增進のための快適な走行状態 が期待される. そこで菅原らの先行研究 ${ }^{5)}$ 参考とし, 人力 ロボテイクスに基づく車輪軸制御を導入する。 モー夕を用い た場合と同様に車輪軸を制御できるため, 従来提案されてい る障害物回避 ${ }^{15)}$ や段差回避 ${ }^{16)}$ などの安全制御技術や, 人と

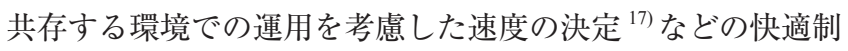
御を実装できる。

図 2 に MPT の構成と概念 ${ }^{1)}$ 示す. MPT は2 2 つの゚ウ ダクラッチ（PC. A, PC. B ) により構成される. MPTの入 力軸は PC. A には直接, PC. B には減速比 $1: 1$ の菌車を介 して入力される.これにより PC. A に対して PC. B は角速度 ならびにトルクの大きさが等しい逆回転が入力される。 一方 で MPT の出力軸は PC. B とは直接, PC. A とは減速比 $1: 1$ のプーリとベルトを介して接続される。 これにより PC. A を つなぎ, PC. B を切った場合では MPT の入力と出力が同方

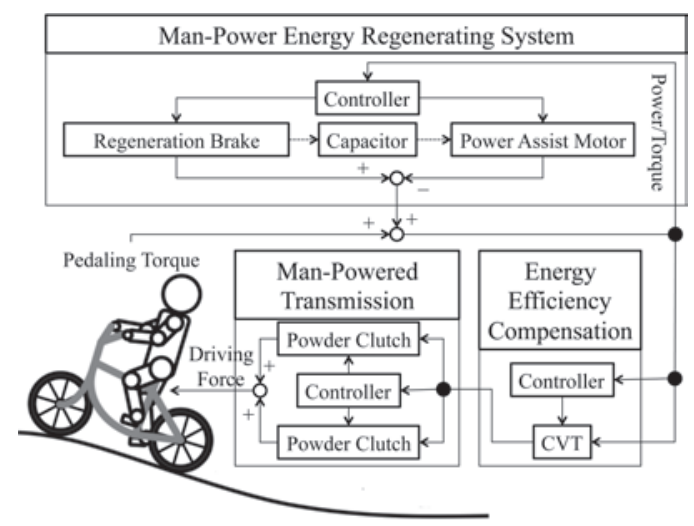

図 1 ロハス・モビリティのコンセプト

ロハス・モビリティは人カロボティクスに基づく駆動装置を備え, 人力エネルギ回生システムおよびエネルギ効率補償システムにより 搭乗者の健康で持続可能な生活を補助することをコンセプトとして いる. 


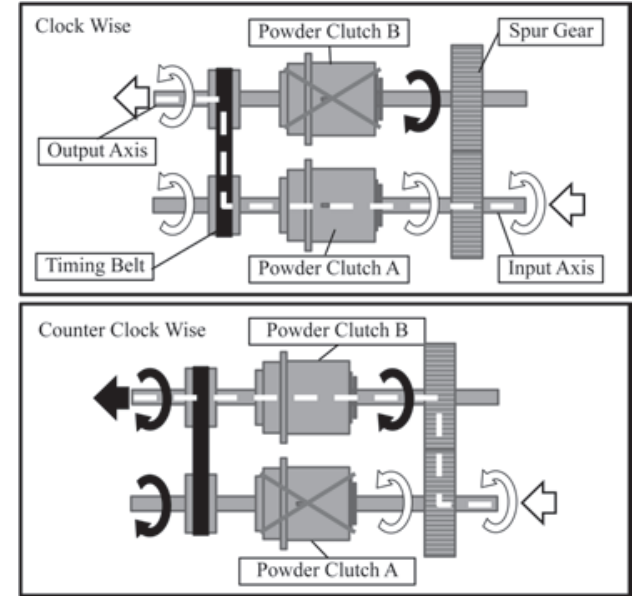

図 2 人カトランスミッションの構造

2 つのパウダクラッチ, ベルト, ギアから構成される. 定方向の回 転の入力（白矢印）に対し，接続するクラッチを切り替えることで 出力（黒矢印）の回転方向を制御可能である.

向に回転する. 逆に PC. A を切り, PC. B を繋いだ場合では MPT の入力と出力は逆方向に回転する.これにより回転方 向を制御する。

また，パウダクラッチは内部に磁性粉末が充填されており， 励磁する磁界の強さにより粉末の摩擦を操作し, 伝達卜ルク を制御できる。したがって，PC．A， PC. B どちらを接続する かにより回転方向が制御でき, 励磁量によりトルクが制御で きるため, MPT の出力軸はモー夕と同様に制御可能である.

ここでパウダクラッチはその構造より, 入出力軸間でト ルクは伝達されるが, 角速度は一致しない. したがって, MPT において入力軸まわりのトルクを $\tau_{p i}(t) \in \mathbb{R}$, 角速度を $\omega_{p i}(t) \in \mathbb{R}$ とし, 出力軸まわりのトルクを $\tau_{p o}(t) \in \mathbb{R}$, 角速 度を $\omega_{p o}(t) \in \mathbb{R}$ としたとき次の関係が成り立つ。

$$
\left\{\begin{aligned}
\tau_{p i} & =\tau_{p o} \\
\omega_{p i} & \neq \omega_{p o}
\end{aligned}\right.
$$

\section{2 人カエネルギ回生システム MERS}

ロハス・モビリティにおける目標の一つに搭乗者の健康増 進と持続可能性がある. このために, 本研究ではモビリティ の運動制御だけでなく, 入力側すなわち搭乗者のペダル運動 を制御することも考える. 人力によるペダル運動を機械シス テムの一部として考えたとき, 原動機とは違い動力が不安定 であることが課題となる，また，電流を制御するモー夕やア クセルを調整するエンジンなどと違い, 入力側の出力を操作 出来ないという特徴もある。

ここで MPT は式（1）の関係を持つため, ペダル軸まわり と車輪軸まわりトルクは従属となり, 角速度は独立となる. したがって, MPT が車輪を制御するときに必要とするトルク と入力であるペダル軸まわりのトルクは, 機構全体の減速比 倍となる，これは作用反作用によるものである，一方で，車 輪の角速度は車輪軸まわりに発生したトルクに基づき, 動力
学的に決まる. 入力であるペダル軸まわりの角速度は MPT より入力側の機構と人の脚部の動力学に基づき決定する.

この特徵よりペダル軸と車輪軸まわりのトルクには図 3 に 示す状態が成り立つ、ペダル軸まわりのトルクが車輪軸まわ りの目標トルクより小さい場合は, モビリティの目標トルク は実現されず，ペダル軸まわりのトルクが出力される．した がってこの場合, モビリティの目標トルクが実現できなくな る. 一方で, ペダル軸まわりのトルクが車輪軸まわりの目標 トルクより大きい場合は, 出力トルクの大小変化に伴いペダ ル軸まわりのトルクが変化する. したがって, 車輪軸まわり のトルクが急激に増減した場合はペダル軸まわりのトルクも 同様に急激に変化する. 感覚的には「急に軽くなる／重くな る」状態となり，継続的なペダリングが困難になる.

この状態を回避するためにペダル軸まわりのトルクを制御 する. 図 1 に示すように, 回生ブレーキならびにモータから 成る人力エネルギ回生システムを用いる。概念的には図 3 中 の左側に示すぺダル軸まわりのトルクより車輪軸まわりのト ルクが小さい場合, 回生ブレーキによりシステムが必要とす るトルクを増加させ, 理想的なペダル軸まわりのトルクと鈞 り合わせる. 一方で右側に示すぺダル軸まわりのトルクが目 標の車輪軸まわりのトルクより小さい場合は, モータにより 不足分を補償する. 回生ブレーキにより発電される電力を キャパシタへ一時的に蓄え, モータで補償するときの電力と して使用する。

ここで自転車に代表されるぺダル運動において，人間は動 力を基準に力を出しているとされる ${ }^{18)}$ 。ここでペダル軸まわ りには次の関係が成り立つ。

$$
P_{H}(t)=\tau_{H}(t) \omega_{H}(t)
$$

ここに, $P_{H}(t) \in \mathbb{R}$ は人間が発生する動力であり, $\tau_{H}(t) \in \mathbb{R}$ はペダル軸まわりのトルク， $\omega_{H}(t) \in \mathbb{R}$ はペダル軸の角速度 である. したがって, モビリティの出力トルクが変化する ことで入力トルク $\tau_{H}(t)$ が変化したとき, ペダル軸の角速度 $\omega_{H}(t)$, すなわちケイデンスが反比例して変化する.

ここで, 自転車競技者などを対象としたペダリングの研 究 ${ }^{19-21)}$ では, 一般の搭乗者では $70 \mathrm{rpm}$ 程度, 自転車競技者 では $90 \mathrm{rpm}$ から $120 \mathrm{rpm}$ 程度でのペダル運動が長時間疲労

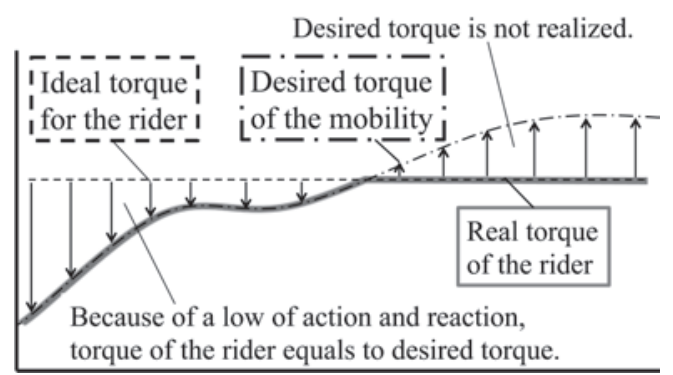

図 3 ペダルによる入力と車輪における出力のトルクの関係 作用反作用から入力と出力軸まわりのトルクは鈞り合うため, 入力 が大きい場合は出力にあわせ入力が小さくなり，入力が小さい場合 は入力にあわせ出力が小さくなる. 前者では入力の理想のトルクが 実現できず，後者では制御のための出力トルクが実現できない. 
しないと議論されている. そこで本研究ではぺダル軸のトル クを操作することで, ケイデンスを長時間疲労しない回転数 へ制御する。

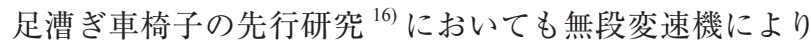
ケイデンスを制御することで, 乗り味が良好になると考察さ れている.この先行研究のシステムではペダル軸と車輪軸は 機械的に接続されているため, 本システムとは違いトルクも 角速度も従属となる。したがって, 走行状況によってはトル クかケイデンスどちらかが実現できない.

ロハス・モビリティではペダル軸と車輪軸の角速度が独立 であるため, トルク，ケイデンス共に目標を実現できる。提 案システムではペダル軸に回生ブレーキとモータが固定され る.したがって,ペダル軸まわりのトルクは次式の関係を持つ.

$$
\tau_{H}(t)=\frac{1}{z(t)} \tau_{o}(t)+\tau_{m}(t)-\tau_{b}(t)
$$

ここで, $\tau_{o}(t) \in \mathbb{R}$ は車輪軸まわりのトルクとし, $\tau_{m}(t) \in \mathbb{R}$ はモータトルク， $\tau_{b}(t) \in \mathbb{R} は$ 回生ブレーキによるトルクとす る. $z(t) \in \mathbb{R}$ をペダル軸から車輪軸までの減速比とする.ケ イデンスの目標値を $\omega_{H d} \in \mathbb{R}$ としたとき，式 (2)，(3) より 次式によりモータまたはブレーキのトルクを操作し, ケイデ ンスを制御する。

$$
\begin{gathered}
\tau_{m}(t)= \begin{cases}\frac{P_{H}(t)}{\omega_{H d}}-\frac{1}{z(t)} \tau_{o}(t) & \left(\frac{P_{H}(t)}{\omega_{H d}}>\frac{1}{z(t)} \tau_{o}(t)\right) \\
0 & \left(\frac{P_{H}(t)}{\omega_{H d}} \leq \frac{1}{z(t)} \tau_{o}(t)\right)\end{cases} \\
\tau_{b}(t)= \begin{cases}\frac{P_{H}(t)}{\omega_{H d}}-\frac{1}{z(t)} \tau_{o}(t) & \left(\frac{P_{H}(t)}{\omega_{H d}}<\frac{1}{z(t)} \tau_{o}(t)\right) \\
0 & \left(\frac{P_{H}(t)}{\omega_{H d}} \geq \frac{1}{z(t)} \tau_{o}(t)\right)\end{cases}
\end{gathered}
$$

これにより,ペダル軸まわりのケイデンスは最適值 $\omega_{H d}$ を 維持し, 車輪軸まわりにおいては目標のトルク $\tau_{o}(t)$ が実現で きる。

\section{3 エネルギ効率補償システム EECS}

MPT では式（1）に示す関係が成り立つ.このとき MPT の入力軸まわりの動力を $P_{p i}(t) \in \mathbb{R}$, 出力軸まわりの動力を $P_{p o}(t) \in \mathbb{R}$ とすると, エネルギ保存則より次式が成り立つ.

$$
P_{p i}(t)=P_{p o}(t)+P_{l}(t)
$$

ここで, $P_{l}(t) \in \mathbb{R} は$ ぱウダクラッチ内で摩擦により熱に変 化し，損失となるエネルギである，エネルギはトルクと角 速度の積で求まるため, 次式の関倸が成り立つ.

$$
P_{l}(t)=\tau_{p i}(t) \omega_{p i}(t)-\tau_{p o}(t) \omega_{p o}(t)
$$

式（1）の関係より次式のように変形できる.

$$
P_{l}(t)=\tau_{p i}(t)\left(\omega_{p i}(t)-\omega_{p o}(t)\right)
$$

これより MPT の入出力の角速度の差によりエネルギ損失が 発生することがわかる. よってエネルギの損失を小さくする ためには, MPT の入出力軸の速度差をなくすよう操作する
必要がある.

本研究では，これを実現するために MPT 入力軸に無段変 速機を用いる. 無段変速機により入力軸の角速度を操作する ことで，パウダクラッチに扔けるエネルギ損失を制御する. 無段変速機の減速比を $z_{n}(t) \in \mathbb{R}$ とすると要素の接続より次 式の関係が求まる.

$$
\begin{aligned}
& \tau_{p i}(t)=z_{p} z_{n}(t) \tau_{H}(t) \\
& \omega_{p i}(t)=\frac{1}{z_{p} z_{n}(t)} \omega_{H}(t)
\end{aligned}
$$

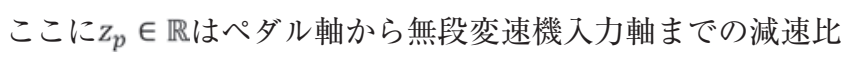
である.

パウダクラッチの入出力軸の回転数を等しくした結果, モ ビリティの出力軸まわりのトルクが実現できなくなると, 走 行制御が不安定になることが考えられる. そこで本研究では, 出力トルクが補償されているときのみエネルギ損失をなくす よう，次式に基づきギア比を決める。

$$
z_{n}(t)= \begin{cases}\frac{\omega_{H}(t)}{z_{p} \omega_{p o}(t)} & \tau_{p o}(t)>\tau_{H}(t) \frac{\omega_{H}(t)}{\omega_{p i}(t)} \\ \frac{\tau_{p i}(t)}{z_{p} \tau_{H}(t)} & \text { else }\end{cases}
$$

実際には，不連続にギア比が変化することのないよう制御 する.

\section{4. ロハス・モビリティ試作機}

図 4 に設計したロハス・モビリテイ試作機の図面を示し， 図 5 に試作中のロハス・モビリティを示す. 図4に示すように, モビリティは 3 輪自転車の機構を模した形状を採用している. 後部に駆動モジュールを備え, その内部にMPT, MERS, EECS を搭載する. モビリティの前後への推進および旋回は 後輪の 2 輪により制御される. 図 6 にそれぞれの機構の接続 を示す。

本モビリティに打いて, 旋回は左右の車輪の速度差により 生成する。そそのた，自転車のようにハンドル形状のインタ フェースを持つが, ハンドル軸と前輪のステアリング軸が接 続されておらず，それぞれ独立して回転する。ハンドル軸の 角度は別途角度センサによって計測し, システムへの入力と して使用する. また, 前輪は車輪の接地点と回転軸にオフセッ トを持たせることで, キャスタとして回転軸を従動するよう にする。

後部駆動モジュールには MERS, EECS, MPT が搭載され ており、ペダリングによる動力をチェーンにより入力するこ とで，モビリティの知的動作を実現する. 具体的にはペダル による動力をMERS に伝達し, ペダル軸まわりのトルクと 回転数を搭乗者へ最適に制御する. MERS と MPT の間には EECS が搭載され，MPTにおけるエネルギ損失を抑制する。 出力の左右 2 輪の車輪はそれぞれ MPT によりトルクが制御 され，目標の運動を実現する。 


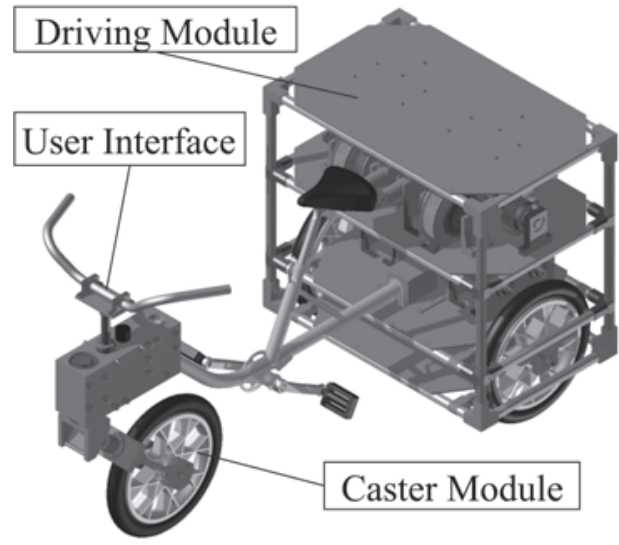

図 4 ロハス・モビリティ（3D-CAD 図）

3 輪自転車の機構を採用し, 後部駆動モジュールに提案する各制御 システムを搭載する. 後輪 2 輪の速度差により旋回するため, 前輪 はキャス夕機構である。

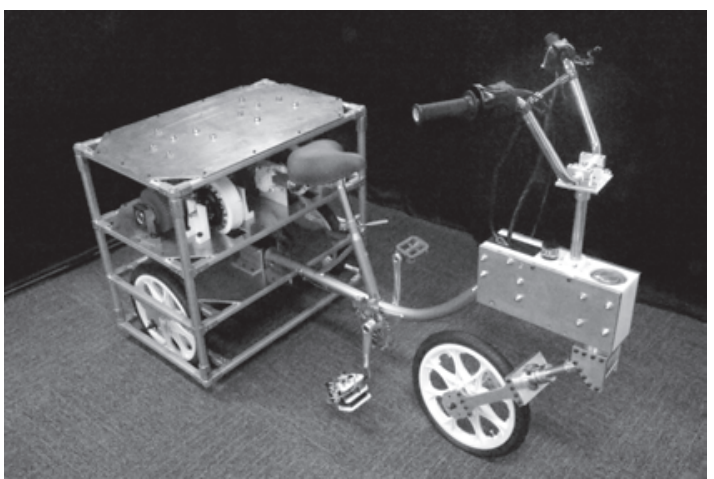

図 5 ロハス・モビリティ試作機

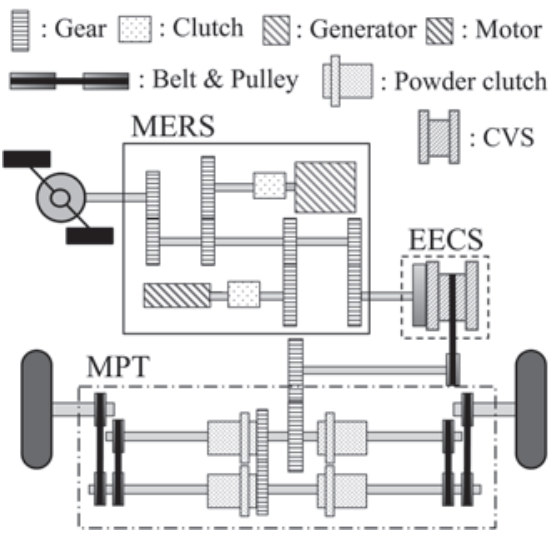

図 6 駆動モジュール機構

ペダルから車輪までの機構の接続. ペダルによる動力は MERS へ 伝達され, ペダル軸まわりのトルクと回転数を搭乗者へ最適に制御 する.MERS と MPTの間にはEECSが搭載され，MPTにおける エネルギ損失を抑制する. 出力の左右 2 輪の車輪はそれぞれ MPT によりトルクが制御され，目標の運動を実現する。

これらの制御用のコンピュータやセンサデバイスならびに クラッチ等の駆動用のバッテリは別途搭載し, それらに給電 する. ハンドル形状の操作インタフェースには各種操作用の ボタンや, バイクにおけるアクセルと同様の速度入力のため の機構などを搭載し, 搭乗者からの操作を受け付ける.

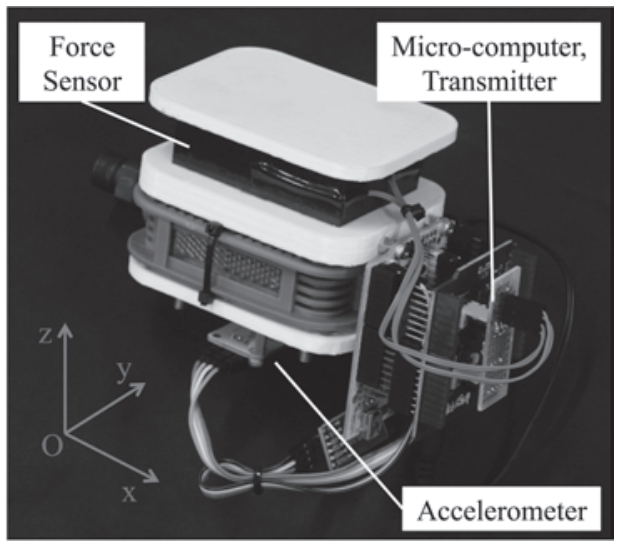

図 7 ペダルによる入力と車輪における出力のトルクの関係 自転車のペダルと置換可能な独立した機構として設計製作されてい る. 踏面下部にはひずみゲージによる力センサを, ペダル下部には 加速度センサを搭載する。 それぞれの情報はペダルに接続されるマ イコンにより処理され, ペダル軸まわりのトルク，ケイデンスおよ び動力の情報として変換する。得られた情報は Bluetoothにより制 御システムへ送信される.

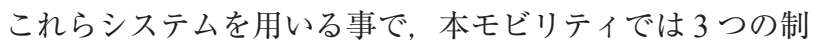
御モード（完全自律モード, 操作モード, 動作アシストモード) を想定している．完全自律モードでは，人間は動力を入力す るのみで操作せず，モビリティは予め設定された軌道上を動 的な変化に対応しつつ走行する．操作モードではあたかも自 転車に乗っているかのように動作する，具体的には，操舵方 向はハンドル軸が向いている方向とすることで，ハンドル軸 と前輪が接続されているかのような運動特性を実現する. 前 後進については,アクセルにより制御する。動作アシストモー ドでは，操作モードと同様に走行するが，環境をセンサで計 測する．搭乗者が障害物や段差などの対応が遅れた場合など においては，先駆けて運動を制御し，安全制御を実現する。

また，式（4)，（5）に基づく制御を実現するためには，人 力によるペダリング時に実際に出力されるトルク $\tau_{o}(t)$ と入力 される動力 $P_{H}(t)$ の值が必要である. 本研究では前者につい ては，パウダクラッチの目標トルクを用いることとし，後者 については実測する。図 7 に本研究で開発した動力計測ぺダ ルのプロトタイプを示す.

\section{5. おわりに}

本研究では健康増進機能・環境親和性・先進安全性を兼 ね備える知的制御可能な乗り物として， ロハス・モビリティ を提案し，その技術開発に取り組んでいる。 ロハス・モビリ ティは，人力ロボティクスに基づく駆動機構である人力トラ ンスミッション，ペダリングによる動力の入力を有効に利用 する人力エネルギ回生システム, 動力の伝達効率を調整する エネルギ効率補償システムから構成される. 本記事では, こ れらの機能及び技術開発状況について述べた。

本研究では, 実際に搭乗可能なモビリティとしてシステム を構築しており，今後，限定された環境を想定して実際に搭 
乗者が消費するエネルギとモビリテイの走行エネルギに着目 した検証を進める。また, 環境への影響を議論し, その有効 性を明らかにしていく予定である。

\section{謝辞}

本研究の一部は競輪の補助（26-99，27-123）を受けて実 施した。この場を借りて感謝の意を表す.

\section{参考文献}

1）菅原雄介, 小林了：人力ロボティクスの研究（第 1 報, 1 自由度関節機構の試作)，ロボティクスメカトロニク 久講演会 2013，2A1-E01，(2013).

2) 平田泰久, 初雁卓郎, 小菅一弘, 浅間一, 嘉悦早人, 川端邦明：人間と複数の分散型ロボットヘルパーと の協調による単一物体の搬送, 日本機械学会論文集 ( C 編 ), 68(668)，1207-1214, (2002). DOI:10.1299/ kikaic.68.1207

3) 衣川潤, 久保田亮平, 小菅一弘：ドア組み付け作業支 援パートナロボット D-PaDY 一第 1 報 : コンセプトと ドア把持部の設計一, 計測自動制御学会論文集, 53(3), 94-102, (2016).

4) 菅原雄介, 遠藤央, 岡本淳, 松浦大輔, 武田行生: 人 カロボティクスの研究 第 7 報 回生サーボクラッチの動 作実験, 第 21 回ロボティクスシンポジア, 6B3, (2016).

5) 菅原雄介, 潘飛: 人力ロボティクスの研究（第 2 報, 人カパーソナルモビリティの設計), ロボティクスメカ トロニクス講演会 2014，2A1-R02，(2014).

6) 射手園健斗, 渡邊麻友美, 遠藤央, 菅原雄介, 柿崎隆夫: 人力ロボティクスを応用した自立搬送システム, 第 17 回 計測自動制御学会システムインテグレーション部門 講演会, 1G2-4, (2016).

7) Wu, Y., Nakamura, H., Takeda, Y., Higuchi, M. and Sugimoto, K.: Development of a power assist system of a walking chair based on human arm characteristics, Proceedings of the 2006 IEEE/RSJ International Conference on Intelligent Robots and Systems, 4328-4335, (2006). DOI: 10.1109/IROS.2006.282005

8）高橋良彦, 新門励起, 濱岡央圭, 磯村恒, 高橋勝美: 人力移動ロボットの設計に用いる腕の力の測定. ロボ ティクスメカトロニクス講演会 2006, 1P1-A25, (2006).

9) 桝田勇司, 松本治, 廣井富, 高橋隆行, 積山彰, 鄭聖喜: 脚漕ぎ式車輪倒立型パーソナルモビリティ試作 2 号機 の開発，システム構成及び基礎走行実験，ロボティク スメカトロニクス講演会 2012, 1P1-F07, (2012).

10) 中川智皓, 中野公彦, 須田義大: 人力で走行するぺ ダル式倒立振子型安定化車両の制御, Dynamics and Design Conference 2016，641，(2016).
11) 中川智皓, 中野公彦, 須田義大: 人力駆動を適用した 倒立振子型車两の安定化制御, 第 11 回「運動と振動の 制御」シンポジウム講演論文集, 60-363, (2009).

12）吉田義宏, 高橋隆行：足漕ぎ車いす Profhand の両輪駆 動化と後輪部の固定による段差乗り換え性能の改善, ロボティクスメカトロニクス講演会 2012, 2P1-T08, (2012).

13) 安藤翔太郎, 平田泰久, 小菅一弘: 無段変速機とサー ボブレーキを用いた足こぎ車椅子の走行支援制御， 口 ボティクスメカトロニクス講演会 2015, 2A2-J04, (2015).

14) Ray, P. H. and Anderson, S. R.: The cultural creative, Harmony Books, ISBN 0-609-60467-8, (2000).

15) 中村仁彦 : 非ホロノミックロボットシステム 第 5 回動 力学的な非ホロノミック拘束の下での運動制御, 日本口 ボット学会誌, 12(2), 231-239, (1994). DOI: 10.7210/ jrsj.12.231

16) 平田泰久, 原麻美, 村木亜沙美, 小菅一弘 : パッシブ 型知的歩行支援機のための環境適応型運動制御, 日本 機械学会論文集 (C 編), 72(719)，2185-2192，(2006).

17) 小林彩乃, 龟崎允啓, 横山悠太, 柳川勇人, 菅野重樹 : 人とロボットの協調移動におけるロボットの行動と人 の印象 の関連性評価, 第 17 回 計測自動制御学会シス テムインテグレーション部門講演会, 3E3-4, (2016).

18）中西安弘, 轟寛, 藤野智一: 人と自転車のマッチング 評価, バイオメカニクス研究，8(1)，65-77, (2004).

19）高石鉄雄：最適なペダリング速度, バイオメカニクス 研究, 8(1)，43-51, (2004).

20) 矢部広樹, 今井正樹, 久保裕介, 安田幸平, 西田裕介： 自転車エルゴメータに扔けるペダルの回転数の違いが 生体に及ぼす影響 一心拍一定負荷による検討一, 理 学療法科学, 22(2), 215-218, (2007). DOI: 10.1589/ rika. 22.215

21) Chavarren, J. and Calbet, J. A.: Cycling efficiency and pedaling frequency in road cyclists, European Journal of Applied Physiology, 80(6), 555-563, (1999). DOI: $10.1007 / \mathrm{s} 004210050634$

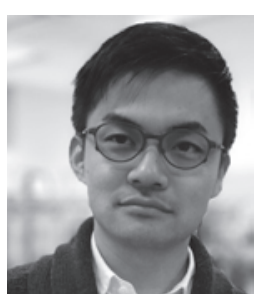

遠藤 央（えんどうみつる）

2009 年東北大学大学院工学研究科博士 課程後期 3 年の課程修了. 同年日本大学 工学部助手. 2010 年より日本大学工学 部助教. 現在に至る. 持続可能なシステ ムの構築を目標とし, 環境観測システム や人力駆動型ロボット, 太陽パネル保守システムの研究に 従事. 博士 (工学). 日本機械学会, 日本ロボット学会, 計 測自動制御学会, 日本ロボット学会, ライフサポート学会, 日本太陽エネルギ学会, IEEEの会員.

(バイオメカニズム学会正会員) 